\title{
Aspek Hukum Tentang Abortus Provocatus Therapeuticus Di Indonesia
}

\author{
Kemal Fikar Muhammad \\ Universitas Hang Tuah Surabaya \\ Email: kemal.fikar@gmail.com \\ Diterima: Desember 2019; Dipublikasikan Januari 2020
}

\begin{abstract}
ABSTRAK
Aborsi adalah salah satu masalah klasik yang selalu menarik untuk diperdebatkan, dalam KUHP aborsi dilarang karena alasan apa pun, baik aborsi provokatus theurapetic maupun aborutus krimis, dalam undang-undang nomor 36 tahun 2009 tentang kesehatan diberikan pengecualian terhadap aborsi dengan alasan indikasi kedaruratan medis. Berdasarkan prinsip di atas, beberapa masalah dapat dirumuskan, yaitu apakah aborsi provokatus theurapetic adalah kejahatan, bagaimana hukum mengatur aborsi yang tidak ditunjukkan secara medis. Metode pendekatan yuridis normatif adalah menguji hukum tertulis dari berbagai aspek dengan pendekatan statuta dan pendekatan konseptual. saran yang dapat disampaikan adalah abortus provocatus bukanlah langkah terbaik yang bisa dipilih, tetapi dalam kondisi yang membahayakan kesehatan, perlu adanya pengaturan yang lebih rinci yang memberikan rasa perlindungan dan asuransi kesehatan.
\end{abstract}

Kata Kunci: provokasi aborsi, pembaruan hukum nasional, tindak pidana

\begin{abstract}
Abortion is one of the classic issues that is always interesting to debate, in the Criminal Code abortion is prohibited for any reason, both theurapetic provocatus abortion and aborutus criminalis, in law number 36 of 2009 regarding health is given an exception to abortion on the grounds of indications of medical emergencies. Based on the above principle, several problems can be formulated, namely whether the theurapetic provocatus abortion is a crime, how the law regulates abortion that is not indicated medically. The normative juridical approach method is to examine written law from various aspects with the Statute Approach and Conceptual Approach. The suggestion that can be conveyed is that Abortus Provocatus is not the best step that can be chosen, but in conditions that endanger health, it is necessary to need more detailed arrangements that give a sense of protection and health insurance.
\end{abstract}

Keyword : abortion provocatus, national law renewal, criminal offense 


\section{PENDAHULUAN}

Saat ini Abortus menjadi salah satu masalah yang cukup serius, dilihat dari tingginya angka aborsi yang kian meningkat dari tahun ke tahun. Di Indonesia sendiri, angka Abortus atau pembunuhan janin per tahun sudah mencapai 3 juta. Angka yang tidak sedikit mengingat besarnya tingkat kehamilan di Indonesia. Selain itu, ada yang mengkategorikan Abortus itu pembunuhan. Ada yang melarang atas nama agama. Ada yang menyatakan bahwa Janin juga punya hak hidup sehingga harus dipertahankan, dan lain-lain (http://regional.kompasiana.com, Akses Jan. 2019). Dalam hukum pidana Indonesia (KUHP) abortus provocatus criminalis dilarang dan diancam hukuman pidana tanpa memandang latar belakang dilakukannya dan orang yang melakukan yaitu semua orang baik pelaku maupun penolong abortus (Laduri, 2016)

Berbicara mengenai aborsi akan menimbulkan berbagai tanggapan dan penilaian yang berbeda-beda pada masing- masing individu karena adanya perbedaan pengetahuan dari diri mereka sehingga sikap yang ditimbulkannya pun berbeda. Aborsi berasal dari kata abortus yang artinya gugur kandungan/keguguran (Teranggono, Murniati, Suciningtyas, 2016). Aborsi sudah perlu mendapat perhatian melalui pengaturan yang lebih bijak untuk menghindari praktek aborsi tidak aman dan pemenuhan hak reproduksi perempuan maupun hak azasi perempuan dan janin. Legalisasi aborsi perlu diperhatikan lebih bijak tetapi bukan dalam pengertian memberikan liberalisasi aborsi(Yuke Novia Langie, 2014).

Perdebatan mengenai aborsi di Indonesia akhir-akhir ini semakin ramai karena dipicu oleh berbagai peristiwa yang mengguncang sendi-sendi kehidupan manusia. Kehidupan yang diberikan kepada setiap manusia merupakan Hak Asasi Manusia yang hanya boleh dicabut oleh pemberi kehidupan tersebut. Berbicara mengenai aborsi tentunya kita berbicara tentang kehidupan manusia karena aborsi erat kaitannya dengan wanita dan janin yang ada dalam kandungan wanita (Charisdiono, 2007).

Dalam kehidupannya manusia hampir selalu terjadi hubungan hukum. Hal ini disebabkan pada dasarnya manusia mempunyai hasrat untuk hidup teratur, akan tetapi keteraturan bagi seseorang belum tentu teratur bagi orang lain. Oleh sebab itu diperlukan kaedah-kaedah yang mengatur kehidupan manusia, agar kepentingannya tidak berbenturan atau bertentangan dengan individu dan masyarakat yang lain. Salah satu masalah yang diatur dalam KUHP yang berlaku di Indonesia adalah masalah aborsi, dan saat ini telah diatur lebih lanjut dalam undang-undang tentang kesehatan nomor 36 tahun 2009. Masalah aborsi atau lebih dikenal dengan istilah pengguguran kandungan, keberadaannya merupakan suatu fakta yang tidak dapat dipungkiri dan bahkan menjadi bahan bahasan yang menarik serta dilema yang saat ini menjadi fenomena sosial . Aborsi merupakan cara yang paling sering digunakan mengakhri kehamilan yang tidak diinginkan, tetapi juga cara yang paling berbahaya. Aborsi menurut terjadinya dibedakan atas Abortus spontan, yaitu aborsi yang terjadi dengan sendirinya tanpa disengaja atau dengan tidak didahului faktor-faktor mekanis atau medisialis, semata-mata disebabkan oleh faktor alamiah, dan Abortus provokatus yaitu aborsi yang disengaja tanpa indikasi medis, baik dengan obat-obatan maupun dengan alat-alat. Aborsi jenis ini dibagi lagi menjadi Abortus medisinalis (Abortus Therapeuticus) merupakan aborsi karena tindakan kita sendiri, dengan alasan bila kehamilan dilanjutkan, dapat membahayakan jiwa ibu (berdasarkan indikasi medis). Biasanya perlu mendapat persetujuan 2 sampai 3 tim dokter ahli (Notoatmodjo, 2010).

Berjuta-juta wanita setiap tahunnya mengalami kehamilan yang tidak diinginkan. Beberapa kehamilan berakhir dengan kelahiran tetapi beberapa diantaranya diakhiri 
dengan Abortus. Abortus adalah ancaman atau pengeluaran hasil konsepsi sebelum janin dapat hidup di luar kandungan dan sebagai batasan digunakan kehamilan kurang dari 20 minggu atau berat janin kurang dari 500 gram. Atau sebelum 22 minggu menurut World Health Organisasion atau WHO.

Diperkirakan frekuensi keguguran spontan berkisar antara 10-15\%. Namun demikian, frekuensi seluruh keguguran yang pasti sukar ditentukan, karena Abortus buatan banyak yang tidak dilaporkan, kecuali bila telah terjadi komplikasi. Juga karena sebagian keguguran spontan hanya disertai gejala dan tanda ringan, sehingga wanita tidak datang ke dokter atau rumah sakit (http://regional.kompasiana.com, Akses Jan. 2019). Dalam pendekatan medis, aborsi terdiri dari dua macam yaitu aborsi spontan (Abortus Spontaneous) dan aborsi yang disengaja (Abortus Provocatus). Abortus Provocatus ialah penghentian atau pengeluaran hasil kehamilan dari rahim sebelum waktunya. Aborsi yang terjadi karena perbuatan manusia dapat terjadi baik karena didorong oleh alasan medis, misalnya karena wanita yang hamil menderita suatu penyakit dan untuk menyelamatkan nyawa wanita tersebut maka kandungan harus digugurkan (Kusumaryanto, 2002).

Selanjutnya Abortus Criminalis, yaitu Abortus yang terjadi oleh karena tindakan-tindakan yang tidak legal atau tidak berdasarkan indikasi medis dan biasanya dilakukan secara sembunyi-sembunyi oleh tenaga yang tidak terdidik. Aborsi merupakan salah satu penyebab kematian wanita dalam masa subur di negara-negara berkembang. Aborsi (pengguguran kandungan) merupakan masalah yang cukup pelik, karena menyangkut banyak aspek kehidupan manusia yang berkaitan dengan etika, moral dan agama serta hukum. Masalah Abortus Provocatus merupakan cara yang paling sering digunakan mengakhiri kehamilan yang tidak diinginkan, meskipun merupakan cara yang paling berbahaya. Abortus Provocatus dibagi dalam dua jenis, yaitu Abortus Provocatus Therapeuticus dan Abortus Provocatus Criminalis. Abortus Provocatus Therapeuticus merupakan Abortus Provocatus yang di lakukan atas dasar pertimbangan kedokteran dan di lakukan oleh tenaga yang mendapat pendidikan khusus serta dapat bertindak secara profesional .

Sementara Abortus Provocatus Criminalis adalah Abortus Provocatus yang secara sembunyi-sembunyi dan biasanya oleh tenaga yang tidak terdidik secara khusus, termasuk ibu hamil yang menginginkan perbuatan Abortus Provocatus tersebut. Abortus Provocatus Criminalis merupakan salah satu penyebab kematian wanita dalam masa subur di negara-negara berkembang. Abortus (pengguguran kandungan) merupakan masalah yang cukup pelik, karena menyangkut banyak aspek kehidupan manusia yang berkaitan dengan etika, moral dan agama serta hukum. KUHP tidak membedakan antara Abortus Provocatus Therapeuticus dan Abortus Provocatus Criminalis. Semua Abortus, tanpa memandang alasan-alasannya, merupakan suatu tindakan yang dapat dikenai sanksi pidana. Dalam konteks kehidupan sehari-hari, masalah pengguguran kandungan tampak terpendam dan tanpa gejolak. Namun demikian, praktik pengguguran kandungan yang dilakukan oleh orang-orang yang tidak bertanggung jawab berjalan terus secara sembunyi-sembunyi. Bahkan akhir- akhir ini media massa menulis tentang Abortus atau pengguguran kandungan yang dilakukan tenaga medis.

Praktik Abortus sudah bukan rahasia lagi, terutama sebagai akibat dari semakin meluasnya budaya pergaulan bebas dan prostitusi dewasa ini. Juga dengan semakin meningkatnya kasus-kasus kehamilan di luar nikah dan multiplikasi keragaman motivasi. Hal tersebut pada gilirannya mendorong orang-orang tertentu cenderung menggugurkan kandungan sebagai solusi untuk menghilangkan aib. Di dalam KUHP tindakan pengguguran kandungan yang disengaja digolongkan ke dalam 
kejahatan terhadap nyawa (Bab XIX Pasal 346 sampai dengan Pasal 349 KUHP). Namun dalam pasal 15 Undang-undang Nomor 23 Tahun 1992 Tentang kesehatan dinyatakan bahwa dalam keadaan darurat sebagai upaya untuk menyelamatkan jiwa ibu hamil atau janinnya, dapat dilakukan tindakan medis tertentu. Undang-undang ini telah dirubah menjadi Undang-undang Nomor 36 tahun 2009 tentang Kesehatan, karena undang-undang nomor 23 Tahun 1992 tentang kesehatan tidak sesuai lagi dengan kebutuhan dan tuntutan pembangunan kesehatan, dimana pembangunan kesehatan diarahkan untuk mempertinggi derajat kesehatan yang besar artinya bagi pembangunan dan pembinaan sumber daya manusia dan sebagai modal bagi pelaksanaan pembangunan nasional yang pada hakekatnya adalah pembangunan manusia seutuhnya dan pembangunan seluruh masyarakat Indonesia sesuai dengan cita-cita bangsa Indonesia sebagaimana dimaksud dalam pembangunan Undang-undang dasar 1945 melalui pembangunan nasional yang berkesinambungan berdasarkan pancasila dan Undangundang dasar 1945. Keberadaan praktik aborsi kembali mendapat perhatian dengan disyahkannya Undang-Undang Nomor 36 Tahun 2009 Tentang Kesehatan. Meski demikian Undang-undang ini menimbulkan kontroversi diberbagai lapisan masyarakat karena adanya pasal-pasal yang mengatur mengenai aborsi dalam praktek medis Pasalpasal tersebut adalah pasal 75, 76 dan 77. Dengan demikian jelas bagi kita bahwa melakukan Abortus dapat merupakan tindakan kejahatan, tetapi juga bisa merupakan tindakan legal yang dibenarkan undang-undang.

Pada beberapa peraturan perundang-undangan yang berlaku di Indonesia dan dikaitkan dengan keyakinan yang dipegang teguh oleh masyarakat, terdapat penafsiran yang berbeda mengenai aborsi. Jika menilik apa yang terdapat Undang- Undang tentang Kesehatan, aborsi dapat dilakukan namun dengan syarat-syarat tertentu, hal tersebut tentunya kan berbeda dengan pandangan yang terdapat dalam Undang-Undang tentang HAM, Kitab Undang-Undang Hukum Pidana, dan juga dalam hukum islam itu sendiri (Rustam, 2017).

Dengan demikian maka penulis akan menganalisa tentang Abortus Provocatus Therapeuticus yang memenuhi unsur-unsur pidana maupun yang tidak memenuhi unsur pidana termasuk didalamnya Abortus Provocatus Criminalis. Penelitian yang dipakai adalah yuridis normativ, yaitu penelitian hukum yang mengkaji hukum tertulis dari berbagai aspek, yaitu aspek teori, sejarah, filosofi, perbandingan, struktur dan komposisi, lingkup dan materi, dan konsistensi, penjelasan umum dan pasal demi pasal, formalitas dan kekuatan mengikat suatu UU, serta bahasa hukum yang digunakan, tetapi tidak mengkaji aspek terapan atau implementasinya, menerapkan hukum terhadap situasi tertentu memerlukan keahlian dalam analisis hokum (Marzuki, 2106).

Di dalam penelitian hukum terdapat beberapa pendekatan. Pendekatan-pendekatan yang digunakan dalam penelitian hukum adalah pendekatan undang-undang (Statute Approach), pendekatan historis (Historial Approach), pendekatan komparatif (Comparative Approach), (Case Approach) dan pendekatan konseptual (Conseptual Approach) (Marzuki, 2106). Dalam penelitian ini, penulis akan menggunakan metode pendekatan undang-undang (Statute Approach) dan pendekatan konseptual (Conseptual Approach).

Pendekatan undang-undang (Statute Approach) dilakukan dengan menalaah semua undang-undang dan reglasi yang bersangkut paut dengan isu hukum yang sedang ditangani. Pendekatan konseptual (Conseptual Approach) beranjak dari pandanganpandangan dan doktrin-doktrin yang berkembang di dalam ilmu hukum. Dengan mempelajari pandangan-pandangan dan doktrin-doktrin di dalam ilmu hukum, peneliti 
akan menemukan ide-ide yang melahirkan pengertian-pengertian hukum, konsep-konsep hukum, dan asas-asas hukum yang relevan dengan isu yang dihadapi (Marzuki, 2106).

Jenis penelitian ini merupakan penelitian hukum normatif. Penelitian hukum normatif adalah penelitian hukum yang berfokus pada norma hukum positif berupa peraturan perundang-undangan.

\section{HASIL DAN PEMBAHASAN}

\section{Abortus Dikaitkan Dengan Hak Asasi Manusia}

Dewasa ini, hampir setiap hari gencar didengung-dengungkan agar kita menghormati hak asasi manusia. Bahkan, kini semakin disadari bahwa kejahatan yang paling menakutkan ialah kejahatan melawan hak asasi manusia, kejahatan melawan kemanusiaan Crime Against Humanity. (J. Guwandi, S.H. Jakarta. 1995), HAM yang kita kenal sekarang berasal dari sejarah panjang berlatar belakang budaya barat, yang muaranya pada Universal Declaration Of Human Rights, yang ditandatangani PBB pada 10 Desember 1948. Menjadi tonggak sejarah perjuangan HAM yang diakui dan harus dilindungi oleh Negara-negara anggota PBB. HAM menjadikan kepatuhan bagi negara untuk melindungi semua hak asasi rakyatnya. Hal ini menampakkan pada tata pergaulan antar bangsa, HAM berposisi sebagai isu global, dimana keberadaban suatu bangsa atau negara diukur dari jaminan HAM terhadap warganya.

Pelanggaran dan pengingkaran HAM bukan saja merupakan tragedi yang bersifat pribadi melainkan dapat menimbulkan keresahan sosial dan bahkan menimbulkan ketegangan antar masyarakat dan negara. Di dalam Piagam HAM PBB dalam hal ini menyatakan: "respect for human rights and human dignity is The pondation of freedom, juctice, and peace in the world". (Titon Slamet Kurnia, Bandung Tahun 1995) Dimana dalam deklarasi yang penting yang mendasari HAM pada umumnya adalah pernyataan bahwa" semua orang lahir dengan kebebasan dan mempunyai martabat dan hak- hak yang sama" selain itu, "hak-hak dan kebebasan dalam deklarasi menjadi hak bagi siapapun tanpa pengecualian, baik berdasarkan jenis kelamin, bangsa, warna kulit, agama, suku dan ras.

Manusia memiliki hak-hak dasar untuk hidup, martabat dan pengembangan kepribadiannya, yang menjadikan tonggak HAM yang berasal dari akal, kehendak dan bakat manusia. Apabila ingin mensejahterakannya memerlukan instrumen dari orangorang berupa pemerintah, yang sekaligus merupakan agen dari masyarakat. Dalam hal ini, pemerintah diciptakan oleh masyarakat dan untuk masyarakat termasuk warganya. Tentunya pemerintah di sini yang "Good Governance" dan disertai dengan partisipasi segenap komponen masyarakat.

Dalam era global ini tak bisa satu negara pun yang menutup diri, pasti terjadi interdependensi antar negara, maka dibutuhkan hubungan antar pemerintah, dengan konsekuensi menerima dan mengadopsi asas-asas hukum internasional sebagai bagian dari hukum nasional, termasuk instrument internasional mengenai HAM. Kendalanya belum biasanya peradilan kita untuk menggunakan instrumen-instrumen dan konvensikonvensi internasional sebagai sumber hukum, dan juga konvensi internasional tentang HAM masih sedikit yang telah diratifikasi. Yang telah diratifikasi di antaranya.

Apabila orang berbicara mengenai hak asasi manusia, tentu saja mengenai hak asasi manusia yang hidup, sebab orang yang mati tidak mempunyai hak asasi lagi. Segala pembicaraan mengenai hak asasi manusia, misalnya hak untuk berbicara dan mengekspresikan pendapat, hak untuk memilih agama, hak untuk merasa aman, hak untuk memilih pemimpin dan sebagainya, dibicarakan dalam kerangka dan demi 
manusia yang hidup. Bahkan ada orang yang menyatakan bahwa manusia berhak untuk mati atas kehendak sendiri (euthanasia). Akan tetapi bagaimanapun juga, hak untuk mati inipun hanya dipunyai oleh manusia yang hidup. Maka "hak untuk hidup" menjadi syarat utama dan mendasar ketika membicarakan mengenai hak asasi manusia. Oleh karena itu, sebelum orang ribut mengenai pelaksanaan hak asasi manusia, orang harus lebih dulu menghormati hak yang paling mendasar yaitu hak untuk hidup. Baru ketika hak paling dasar ini sudah dihormati dan dipraktikkan, baru kita bisa beranjak kelevel berikutnya, yakni hak-hak asasi yang lainnya. Bagi seorang manusia, hidup adalah nilai fundamental untuk merealisasikan nilai-nilai lainnya.

Penghormatan terhadap hak untuk hidup adalah kondisi dasar supaya manusia bisa berfungsi dengan semestinya. Memang benar bahwa selain hidup fisik manusia, masih ada banyak nilai hidup, meskipun adalah hak hidup yang paling fundamental, tidak selalu menjadi hak yang paling tinggi, atau demi mencapai nilai yang lebih tinggi, misalnya demi tanah air, demi orang yang dikasihi dan lain sebagainya. Akan tetapi, disini ada faktor esensial yang tidak boleh dilupakan, yakni persetujuan pribadi. Orang tidak boleh dikorbankan dengan alasan apapun tanpa persetujuan dari dirinya yang diserahi tugas untuk menjaga hidupnya. Dengan alasan-alasan tertentu yang luhur, bisa dibenarkan kalau ada orang yang mengorbankan hidupnya. Akan tetapi, tidak pernah bisa dibenarkan kalau hidup manusia dikorbankan demi alasan tertentu. Maka penghormatan terhadap hak asasi untuk hidup menjadi prasyarat utama untuk suatu masyarakat yang bermartabat dan berbudaya luhur.

Tren kekinian yang juga berentetan jauh kebelakang dengan tradisi dan budaya masyarakat di negara-negara telah terjadi diskriminasi ataupun dominasi dari sekelompok orang terhadap kelompok lainnya, terutama yang berkaitan dengan jeniskelamin, sehingga menimbulkan penindasan dan kesewenang- wenangan terhadap HAM, dan wanitalah yang menjadi korban. Dalam hal ini terkait dengan masalah reproduksi pada wanita, yang mengganggu atau merugikan kesehatannya, sehingga tidak ada jaminan tentang hak-reproduksi.

Kemudian, telah muncul berbagai upaya dan perjuangan untuk menentang penindasan dan kesewenangan tersebut, yakni perjuangan penyetaraan gender. Dalam konteks seperti itu, menjadi penting pemahaman HAM yang akan dikaitkan dengan kesehatan reproduksi. Ditinjau dari perspektif HAM, seorang wanita mempunyai hak untuk memperoleh pelayanan Abortus karena merupakan bagian dari hak kesehatan reproduksi yang sangat mendasar. Di dalam Undang-undang No 36 Tahun 2009 tentang kesehatan Pasal 72 juga memuat ketentuan mengenai jaminan setiap orang untuk melakukan reproduksi. Namum dalam hal ini Abortus merupakan suatu kebutuhan yang tidak dapat dihindari bagi wanita yang tidak menginginkan kehamilannya karena adanya beberapa alasan tertentu. Reproduksi merupakan fungsi dari makhluk hidup untuk menurunkan generasi penerusnya, dengan secara alamiah dilengkapi dengan organ-organ yang secara biologis untuk itu.

Demikian juga manusia, penentuan perilaku reproduksi berasal dari hormonhormon yang dimilikinya dan juga adanya alat-alat reproduksi, yang antara betina dan jantan berbeda, untuk memfungsikannya dengan melakukan hubungan seksual. Secara biologis, cara hormon berinteraksi dengan perilaku seksual pada manusia tidak berbeda pada binatang. Yang membedakan adalah manusia dapat melakukan pengendalian dengan pikirannya. Kesehatan reproduksi adalah keadaan kesejahteraan fisik, mental, dan sosial yang utuh, tidak semata-mata bebas dari penyakit atau kecacatan yang berkaitan dengan sistem, fungsi, dan proses reproduksi pada laki-laki dan perempuan.( Undang-Undang Kesehatan No. 36 Tahun 2009 ) Oleh karena itu, kesehatan reproduksi 
berarti bahwa orang dapat mempunyai kehidupan seks yang memuaskan dan aman, dan mereka memiliki kemampuan untuk bereproduksi dan kebebasan untuk menentukan keinginannya, kapan dan frekuensinya. Dalam hal terakhir termasuk, hak pria dan wanita untuk memperoleh informasi dan mengakses terhadap cara-cara KB yang aman, efektif, terjangkau, dan dapat diterima sebagai pilihannya, serta metoda-metoda lain yang dipilih yang tidak melawan hukum, dan hak untuk memperoleh pelayanan pemeliharaan kesehatan yang tepat, yang memungkinkan para wanita mengandung dan melahirkan anak dengan selamat, serta kesempatan memiliki bayi yang sehat (ICPD- Kairo,1994). Membicarakan kesehatan reproduksi tak terpisahkan dengan soal hak reproduksi, kesehatan seksual, dan hak seksual.

Hak reproduksi adalah bagian dari hak asasi yang meliputi hak setiap pasangan dan individual untuk memutuskan secara bebas dan bertanggung jawab jumlah, jarak, dan waktu kelahiran anak, serta untuk memiliki informasi dan cara- cara untuk melakukannya. Kesehatan seksual yaitu suatu keadaan agar tercapai kesehatan reproduksi yang mensyaratkan bahwa kehidupan seks seseorang itu harus dapat dilakukan secara memuaskan dan sehat dalam arti terbebas dari penyakit dan gangguan lainnya. Terkait dengan ini adalah hak seksual, yakni bagian dari hak asasi manusia untuk memutuskan secara bebas dan bertanggung jawab terhadap semua hal yang berhubungan dengan seksualitas, termasuk kesehatan seksual dan reproduksi, bebas dari paksaan, diskriminasi dan kekerasan.

Lepas dari analogi diatas, orang sering membuat pembenaran untuk melakukan Abortus, dengan berpandangan bahwa Abortus adalah pelaksanaan otonomi pribadi seorang wanita untuk mengatur tubuhnya sendiri, menentukan sendiri apa yang baik dan buruk untuk tubuhnya. Namum menurut argument ini masih banyak sekali terdapat kelemahan yang didasarkan pada prinsip, berikut ini :

Pertama, memang benar bahwa semua orang berhak mengatur tubuhnya sesuai dengan apa yang dipandang baik oleh sang empunya tubuh. Bahkan seorang dokter pun tidak berhak melakukan intervensi medis pada tubuh seorang pasien tanpa izin dari yang empunya tubuh. Akan tetapi, harus diingat bahwajanin bukanlah bagian dari tubuh wanita, karena itu sang ibu tidak berhak untuk mengaturnya. Memang benar sel telur itu keluar dari tubuhnya, dan selama belum keluar dari indung telurnya maka ia merupakan bagain dari tubuhnya. Akan tetapi, begitu sel telur itu dibuahi, ia menjadi entitas yang lain sama sekali, dan bukan bagian dari ibunya. Sebagaimana sudah kita lihat dalam bab sebelumnya, bahwa sejak pembuahan, si janin sudah mempunyai kode genetik yang lain. Ia sama sekali lain dengan bapaknya dan ibunya. Percampuran kromoson dari bapakibunya yang sama-sama menyumbangkan separuh untuk anaknya tersebut, ternyata membentuk seorang manusia yang unik, yang tidak ada duanya. Ia adalah keunikan golongan darah, struktur tulang, wajah , kepribadian dan sebagainya.

Kalau benar janin adalah bagian dari ibunya, maka harus dikatakan bahwa si ibu mempunyai 4 kaki, 4 tagan, 2 wajah, dan bila janinya laki-laki maka dia mempunyai alat kelamin ganda, pria dan wanita. Benarkah demikian? Program pembuahan artificial, khususnya surrogate mother (ibu yang dititpi janin orang lain), akan lebih mengaris bawahi keterpisahan ini. Kalau ovum orng berkulit putih dibuahi oleh sperma orang berkulit putih, meskipun sesudah pembuahan dimasukkan ke dalam rahim orang berkulit hitam, si bayi akan tetap akan lahir berkulit putih. Secara genetis si ibu kulit hitam itu tidak mempengaruhi apa-apa terhadap si bayi tersebut, meskipun si bayi berada selama 9 bulan di dalam kandungannya, dan makan dari gizi yang dimakan si ibu yang berkulit hitam tersebut. Jadi, bagaimanapun juga, sesudah sel telur itu dibuahi, ia akan menjadi 
entitas yang berbeda dari ibunya. Ia bukan bagian dari ibunya lagi, karena itu si ibu tidak berhak untuk mengaturnya sebagaimaan ia mengatur tubuhnya sendiri.

Kedua, hak untuk mengatur tubuhnya sendiri tersebut tentu saja berlaku bagi semua orang. Yang mempunyai hak itu bukan hanya ibu yang mengandung, tetapi semua orang, baik ynag mengandung maupun yang tidak mengandung. Pelaksanaan hak itu tentu saja bisa dibenarkan sejauh tidak mengganggu pelaksanaan hak yang sama dari orang lain. Dengan kata lain, pelaksanaan hak itu tidak pernah bisa dibenarkan kalau pelaksanaanya mengganggu pelaksanaan hak orang lain. Lebih tidak bisa dibenarkan lagi kalau yang diganggu itu adalah hak dasar setiap manusia, yakni hak untuk hidup.

Ketiga, tidak sebanding. Memang harus diakui bahwa kehadiran janin didalam kandungan bagi ibu yang tidak mengiginkannya bisa menjadi beban mental dan menyebabkan penderitaan bagi ibunya. Meskipun demikian, penderitaan si ibu tidak bisa menjadi alasan yang cukup untuk membalas dendam, menimbulkan penderitaan yang lebih besar lagi kepada penyebabnya, yakni janinnya sendiri, apalagi kalau balasan itu sampai menghilangkan hidup si bayi tersebut. Tentu saja hal ini merupakan ketidakadilan. Lebih-lebih kalau balas dendam itu dialamatkan kepada yang lebih lemah dan tak berdaya, jelas tidak bisa dibenarkan. Di sini, yang berlaku ialah prinsip hukum vulnerability yang berlaku dimana-mana, yakni yang kuat harus melindungi yang lemah.

Abortus memang erat kaitanya dengan hak asasi manusia, disatu sisi dikatakan bahwa setiap wanita berhak atas tubuh dan dirinya dan berhak untuk menjalani kehidupan reproduksi dan kehidupan seksual yang sehat, aman, serta bebas dari paksaan. Namum, disatu sisi lagi janin yang ada dalam kandungan juga berhak untuk terus hidup dan berkembang. Dua hal tersebut memang saling bertentangan satu sama lain karena menyangkut dua kehidupan. Jika Abortus yang dilakukan adalah Abortus krminalis tentu saja hal tersebut sangat bertentangan dengan hak asasi manusia. Dalam Undang-Undang HAM juga diatur mengenai perlindungan anak sejak dari janin karena sekalipun seorang ibu mempunyai hak atas tubuhnya sendiri tetapi tetap saja harus kita ingat bahwa hak asasi yang dimiliki setiap orang tetap dibatasi oleh Undang-Undang. Tetapi ketika seorang ibu harus menggugurkan kandungannya dengan indikasi kedaruratan medis yang dideteksi dapat mengancam nyawa ibu atau janin, secara hak sasai manusia dapat dibenarkan karena si ibu tersebut juga punya hak untuk hidup dan mempertahankan kehidupannya.

Abortus memang berhubungan dengan hak wanita untuk melakukan reproduksi dan hak atas tubuhnya. Undang-undang kesehatan sendiri juga memuat ketentuan kebebasan setiap orang untuk bereproduksi. Jika ditafsirkan kebebasan untuk bereproduksi bisa saja membuka cela untuk melakukan Abortus, namum yang perlu kita ingat dan tekankan disini adalah kebebasan setiap orang untuk melakukan reproduksi di sini adalah kebebasan yang bertanggung jawab yang tentunya tidak bertentangan dengan hak asasi manusia.

\section{Abortus Dikaitkan Dengan Hak Hidup Janin}

Berbicara mengenai Abortus, tentu tidak lepas dari janin yang dikandung. Janin nantinya akan berkembang menjadi makhluk hidup yang baru yang terbentuk berdasarkan struktur genetik. Masalah pengguguguran kandungan (Abortus) merupakan persoalan kita bersama sebagai umat manusia, yang selalu berhubungan erat dengan hak hidup dan nilai moral. Dunia dewasa ini, mengalami banyak perkembangan yang sungguh pesat baik dalam bidang teknologi, medis yang memukau manusia, tentunya ada orang yang mempergunakannya sebaik-baiknya, tetapi ada juga yang mempergunakan hal itu bertentangan dengan tuntutan moral. Orang sering tidak melihat lagi nilai dan arti 
hidup sesamanya. Bahkan ada juga orang yang sengaja menggugurkan janin yang ada dalam kandungannya, untuk melarikan diri dari suatu tanggung jawab sebagai seorang ibu. Padahal kewajiban moral mengharuskan untuk menghormati hidup sesama manusia termasuk juga janin yang ada dalam kandungan. Pengguguran merupakan tindakan yang sengaja mengeluarkan buah kandungan dari rahim seorang ibu, sehingga mematikan proses perkembangan dan pertumbuhan janin sebelum tiba saat kelahirannya.

Tindakan yang tidak menaruh rasa hormat terhadap nilai kehidupan janin diakibatkan oleh mereka yang hanya melihat segi kepentingan pribadi saja dan tidak memandang bahwa janin itu adalah manusia yang utuh dan mempunyai hak untuk hidup, merupakan suatu kejahatan durhaka. Tindakan dekadensi moral yang tidak hanya melanda para ibu rumah tangga, tetapi juga telah melanda kaum remaja. Dewasa ini dengan adanya kemajuan teknologi yang canggih dan pesat, beredarnya obat-obatan di pasaran yang begitu bebas praktek dokter, bidan, dukun, dan peralatan lainnya mengakibatkan jumlah pengguguran (Abortus "provocatus") semakin tinggi. Tindakan ini dengan sengaja menggugurkan janin, mematikan proses kehidupan dan perkembangan sebelum tiba saat kelahirannya.

Menggugurkan kandungan berarti "mengakhiri hidup janin dalam tubuhnya sendiri, ibu sebenarnya membunuh sesuatu yang ada dalam hatinya yaitu sikap keibuan. Unsur psikologi-sosial kerap mendukung keputusan tersebut, yang kerap bersikap kurang adil terhadap janin. Kita yakin bahwa tindakan pengguguran itu sendiri membawa banyak akibat pada wanita tersebut antara lain: Secara psikologis menggugurkan kandungan itu akan tetap meninggalkan bekas rasa bersalah, dan bagi orang yang beragama rasa bersalah itu juga berarti religiusnya, artinya wanita yang bersangkutan akan merasa berdosa.

Pengguguran dapat dikatakan memperkosa suatu yang hakiki bagi seorang wanita. Sebab pada umumnya wanita mempunyai naluri "pemberi hidup". Kebanyakan wanita yang sedang hamil mempunyai kesadaran kuat bahwa ia telah membunuh anaknya sendiri. Bahkan tidak jarang terjadi perasaan itu begitu mendalam sehingga tidak mungkin dihilangkan lagi. Pada dasarnya tindakan Abortus provocatus dinilai sebagai dosa yang berat karena membunuh janin yang tidak bersalah. Bayi yang masih dalam kandungan yang belum matang fisik dan mentalnya hendaknya dilindungi serta diperhatikan secara khusus termasuk perlindungan yang sah. Setiap orang yang bertindak berlawanan dengan hak hidup merupakan tindakan yang biadab, suatu penindasan dan merupakan perbuatan jahat. Selain itu tindakan tersebut melanggar hak hidup janin, juga melanggar kewajiban etik hormat terhadap hidup orang lain termasuk manusia yang belum lahir.

Bagaimanapun pengguguran yang dilakukan secara langsung dan sengaja tidak dibenarkan sebab merampas hak janin. Dan setiap pengguguran yang disengaja apa pun bentuknya merupakan suatu tindakan yang tidak dapat diizinkan, sebab memperkosa hak fetus atas kehidupan. Setiap orang percaya bahwa manusia diciptakan oleh Tuhan Allah dan memperoleh kehidupan dari- Nya. Kewajiban untuk menghormati, menghargai dan menjunjung tinggi hidup, bukan saja hidup diri sendiri, tetapi juga hidup sesama manusia baik yang masih ada dalam kandungan maupun yang sudah dilahirkan. Bagaimanapun juga hidup janin yang masih dalam kandungan statusnya bukanlah lebih rendah jika dibandingkan dengan hidup yang sudah dilahirkan. Oleh karena itu ia juga harus dihormati dan sebagaimana layaknya seorang manusia pada umumnya sebagai pribadi yang sedang berkembang dan bertumbuh. Maka dari itu tidak seorang pun berhak menghabisi hidup sesamanya, baik itu hidup yang sudah dilahirkan atau hidup yang masih dalam kandungan. Hidup manusia perlu dilindungi dan dijaga serta dijunjung 
tinggi sebab terkandung nilai-nilai yang luhur. Sebab hidup merupakan anugerah dan kedaulatan cinta yang berasal dari Tuhan sendiri.

Bisikan hati nurani manusia perlu dibentuk dan dididik agar semakin mampu melahirkan pertimbangan yang matang, sehingga seseorang tahu apa yang harus dan apa yang wajib dan apa yang diizinkan dilakukan dalam situasi konkrit. Bila hati nurani telah dibentuk dan dididik untuk lakukan perbuatan baik akan lebih membantu seseorang dalam bertindak dan menjalankan hal-hal yang praktis dalam kehidupan sehari-hari. Maka dari itu agar suara hati dapat memberikan keputusan dan penilaian yang tepat perlu dididik dengan baik. Hati nurani biasanya dipengaruhi perasaan moral yang terbentuk akan melakukan yang baik dan mampu untuk bersikap kritis. Membentuk dan mendidik suara hati berarti: "Bahwa kita terus menerus bersikap terbuka, mau belajar, mau mengerti seluk beluk masalah yang kita hadapi, mau memahami pertimbangan etis yang tepat dan seperlunya membaharui pandangan-pandangan kita.Peranan hati nurani dalam diri manusia adalah sebagai pedoman, pengontrol, memutuskan apa yang baik, atau yang tidak baik, yang boleh atau yang tidak boleh untuk dilakukan seseorang. Selain itu hati nurani berperan sebagai penentu bagi perbuatan yang akan datang, menolong kita untuk mengerjakannya atau menghindarinya dan juga merupakan yakin atas perbuatan yang telah lalu. Hati nurani merupakan sumber pembinaan dan juga sumber rasa sesal.

Hati nurani akan memutuskan sebagai baik hal-hal yang benar-benar buruk. Tidak terlalu berlebihan jika dikatakan bahwa hati nurani yang terbina dan terdidik membuat pribadi seseorang (ibu yang mengandung) lebih tahu dan sadar akan kewajiban terhadap hidup manusia yang masih berada dalam kandungan maupun terhadap hidup manusia yang sudah dilahirkan. Sehingga seorang wanita atau pribadi lain tidak sekehendak hatinya menggugurkan kandungan itu, tetapi tetap berusaha mencari jalan lain yang lebih baik. Kecuali sudah tiada jalan yang lebih baik lagi untuk menyelamatkan hidup keduaduanya. Untuk itu orang perlu pertimbangan dan matang. Sehingga orang tidak melarikan diri dari kesulitan sebagai orang yang pengecut, melainkan menghadapinya dengan tanggung jawab. Sebab "Manusia harus dihormati dan diperlakukan sebagai pribadi sejak saat pembuahan" Hati nurani berperan mempertimbangkan apa yang harus dipilih dan dijalankan oleh manusia. Dan biasanya jalan yang ditunjukkan oleh hati nurani itu baik. Oleh karena itu diharapkan baik wanita, ahli medis tetap memerhatikan bisikan hati nurani.

Masalahnya menjadi sangat bebeda apabila kehamilan itu benar-benar mengancam hidup sang ibu. Dalam kasus ini, Abortus bisa dibenarkan dengan prinsip Legitime defense (pembelaan diri yang sah). Dimana orang berhak untuk membela diri terhadap serangan orang lain yang jelas-jelas mengancam hidupnya. Di sini perlu digarisbawahi dalam kasus kehamilan yang berbahaya, membunuh janin tersebut bukanlah menjadi tujuan perbuatan itu. Tujuan perbuatan itu adalah menyelamatkan hidup ibu, dan kematian janin hanyalah efek dari perbuatan tersebut, yang secara objektif terpaksa harus terjadi. Masih dalam garis yang sama, bisa dikatakan juga bahwa dalam kehamilan yang membahayakan hidup si ibu, kita dihadapkan pada persaingan anatara dua persona yang sama-sama bernilai, tetapi pada jalan yang buntu. Pada prinsipnya, kalau kedua-duanya bisa diselamatkan maka tidak akan ditempuh jalur Abortus dan hak janin untuk hidup tetap akan dipertahankan.

Sekarang bagaimana permasalahannya jika Abortus dilakukan oleh korban perkosaan bukankah dalam hal ini nyawa si ibu tidak terancam dan janin juga dapat lahir tanpa menyebabkan kematian. Dalam UU No.36 Tahun 2009 tentang kesehatan dalam Pasal 75 terkandung makna bahwa kehamilan akibat perkosaan yang dapat menyebabkan trauma psikologis bagi korban perkosaan. Dapat ditarik satu penafsiran bahwa dalam 
kasus ini nyawa sang ibu tidak terancam dan tidak ada indikasi kedaruratan medis yang harus membuat ibu menggugurkan kandungan. Bisa saja anak tersebut dilahirkan kedunia dan kemudian diserahkan kepada panti asauhan atau anak yang lahir tersebut dijauhkan dari sang ibu sehingga tidak akan mengingatkan memori ibu pada kasus perkosaan. Dalam hal ini semuanya kembali kepada hati nurani sang ibu, apakah ingin tetap melahirkan anak tersebut atau tidak. Untuk itu dalam permasalahan ini dibutuhkan bantuan dari konseling dan psikiater yang nantiya akan membantunya untuk mengambil suatu keputusan. Janin yang dikandung akibat korban perkosaan memiliki hak untuk hidup begitu juga sang ibu yang sebenarnya secara fisik mampu untuk melahirkannya namum permasalahannya adalah bagaimana gangguan trauma psikologis yang akan dialami sang ibu setelah melahirkan anak tersebut. Namum penulis beranggapan bahwa menggugurkan janin yang timbul akibat perkosaan melanggar hak janin untuk hidup karena dalam hal ini janin yang dikandung mempunyai hak untuk hidup karena secara kedaruratan medis memang tidak membahayakan nyawa sang ibu dan anak memang dapat terlahir kedunia. Penulis berpendapat bahwa jalan menggugurkan anak hasil perkosaan tidak memberikan solusi yang tepat karena dalam hal perkosaan ini wanita menjadi korban. Ketika dia melakuka n Abortus dia harus mengorbakan dirinya kembali untuk diAbortus dan harus menggugurkan kandungannya sendiri.

Menurut hemat penulis jalan keluar yang tepat adalah dengan memberikan konseling secara khusus baik dari konselor ataupun pemuka agama, dan melakukan terapi khusus kepada korban. Janin yang dikandung juga harus tetap dilahirkan, jika si ibu tidak menginginkan anaknya tersebut dapat dijauhkan dari sang ibu. Setelah pasca melahirkan si korban juga harus tetap diberikan terapi dan konseling khusus kalau memang mengalami tarauma secara psikis sampai dia sembuh dan dapat menerima kembali anak tersebut. Dalam hal ini juga diperluka $n$ bantuan pemerintah dalam melindungi korban perkosaan dan memudahkan anak tersebut dalam pembuatan akte kelahiran sehingga tidak mempersulit anak tersebut kelak ketika besar.

Dalam Undang-undang No. 39 Tahun 1999 tentang hak asasi manusia juga sebenarnya telah dimuat perlindungan terhadap hak janin. Dalam Pasal 53 dikatakan bahwa setiap anak sejak dalam kandungan, berhak untuk hidup, mempertahankan hidup, dan meningkatkan taraf kehidupannya. Anak dalam kandungan yang dimaksud adalah janin yang nantinya akan tumbuh menjadi anak dan berkembang selayaknya manusia. Janin merupakan awal kehidupan yang harus dihormati oleh setiap manusia dan dijaga karena janin nantinya akan tumbuh dan berkembang menjadi manusia yang kelak juga akan menghasilkan hal yang sama. Jadi berapapun usia janin, berapapun dikatakan usia awal kehidupan janin, janin harus tetap dipertahan hidup sepanjang tidak membahayakan kondisi sang ibu dan memang dapat terlahir kedunia tanpa mengancam nyawa ibu dan janin.

Dalam Deklarasi Hak-hak Asasi Manusia (PBB) disebutkan, "Martabat yang tertera dalam pribadi manusia dan hak-hak yang sama dan mutlak dari semua anggota keluarga manusia menjadi dasar kemerdekaan, keadilan, dan perdamaian di dunia." Kita juga tegas mengakui martabat dan hak asasi manusia ini. Mengingat janin adalah manusia, maka ia memiliki martabat dan mengembangkan hak-hak asasi yang sama dengan kita, terutama hak untuk hidup. Menyerang janin dengan Abortus berarti menyerang martabat yang melekat pada kemanusiaan sesama. Kita tidak bisa tinggal diam saat martabat sesama dirampas orang lain. Kita harus menjadi suara bagi janin yang belum dapat bersuara. Dilaporkan, terjadi 30 juta-50 juta praktik Abortus per tahun di 56 negara yang melegalisasi hal itu. Ini merupakan serangan kemanusiaan karena manusia membunuh sesamanya yang lemah. Jika kita melegitimasi serangan ini, tidak ada alasan 
lagi bagi kita untuk menolak perang, pembunuhan, perbudakan, penindasan, dan masalah etika sosial lainnya.

\section{KESIMPULAN}

Abortus Provocatus Therapeutic merupakan Abotus Provocatus yang dilakukan atas dasar pertimbangan kedokteran dan dilakukan oleh tenaga yang mendapat pendidikan khusus serta dapat bertindak secara profesional. Sementara Abortus Provocatus Criminalis adalah abotus provocatus yang dilakukan secara sembunyisembunyi dan biasanya oleh tenaga yang tidak terdidik secara khusus. KUHP tidak membedakan antara Abortus Provocatus Therapeutic dan Abortus Provocatus Criminalis, semua abortus tanpa memandang alasan-alasannya merupakan suatu tindakan yang dapat dikenakan sanksi pidana. KUHP yang merupakan warisan zaman belanda bertentangan dengan landasan dan politik hukum yaitu melindungi segenap bangsa Indonesia untuk memajukan kesejahteraan umum berdasarkan pancasila dan undang-undang dasar 1945, karena melarang Abortus Provocatus tanpa mengecualian. Oleh karena itu dibutuhkan untuk suatu peraturan perundang-undangan yang baru yang mengandung aspek perlindungan hukum yang tinggi bagi para tenaga medis dalam menjalankan kewajibannya. Kebutuhan akan peraturan perundang-undangan baru tersebut dipenuhi dalam undang-undang nomor 36 tahun 2009 tentang kesehatan.

Namun undang-undang nomor 36 Tahun 2009 tentang Kesehatan, ada pengecualian terhadap Abortus Provocatus Therapeutic, akan tetapi pengecualian dimaksud tidak akan berlaku jika anasir-anasir yang termaktub dalam undang-undang nomor 36 Tahun 2009 tidak terpenuhi antara lain jika layanan kesehatan tidak memenuhi persyaratan kesehatan menurut Menteri Kesehatan dan atau tidak adanya izin dari suami yang akan menjalankan abortus. Sehingga Abortus Provocatus Therapeutic yang tidak memenuhi undang-undang nomor 36 Tahun 2009 adalah termasuk Tindak Pidana.

Pengguguran kandungan yang disengaja dengan melanggar berbagai ketentuan hukum disebut Abortus Provocatus Criminalis dalam KUHP menganut prinsip ilegal tanpa kecuali, apapun alasannya tidak dibenarkan oleh norma hukum hal ini disebabkan bahwa pengguguran kandungan ini sangat bertentangan dengan nilai yang hidup dalam bermasyarakat dan merupakan suatu pembunuhan yang dilakukan terhadap janin yang ada dalam kandungan yang seharusnya dilindungi. Dengan demikian Abortus jenis ini memberikan ancaman pidana bagi yang melakukannnya.

\section{DAFTAR PUSTAKA}

Laduri, M. C. (2016). Penegakan Hukum Terhadap Tindakan Aborsi Menurut UndangUndang Nomor 36 Tahun 2009. Lex Crimen, 5(5), 151-158.

Rustam. (2017). Analisis Yuridis Terhadap Tindakan Aborsi Dalam Perspektif Hukum Pidana Indonesia. DIMENSI, 6(3), 475-490.

Teranggono, Murniati, F., \& Suciningtyas, M. (2016). Pengaruh Penyuluhan terhadap Tingkat Pengetahuan Remaja tentang Aspek Kesehatan, Sosial dan Hukum Aborsi pada Siswa SMU N 6 Yogyakarta. Mutiara Medika: Jurnal Kedokteran Dan Kesehatan, 10(2), 153-159. Retrieved http://journal.umy.ac.id/index.php/mm/article/view/1578

Yuke Novia Langie. (2014). Tinjauan Yuridis Atas Aborsi di Indonesia. Lex et Societatis, II(7), 61-71.

Alam, A.S dan Amir Ilyas (2010). Pengantar Kriminologi, P.T Pustaka Refleksi Atmasasmita, Romli. (1997). Kriminologi, Bandung. C.V. Mandar Maju 
Ekotama, Suryono. (2001). Artu Harum, ST Pudji dan Artana, Widi. Abortus Provokatus bagi Korban Perkosaan. Perspektif Viktimologi Kriminologi dan Hukum Pidana.Yogyakarta.

Kusmaryanto (2002). Kontroversi Aborsi. Jakarta: PT. Gramedia Widiasarana Indonesia.

Mutiara, Dali, Kejahatan dan Pelanggaran Kriminal Sehari-hari, Penerbit Nasional Bintang. Indonesia Jakarta,1987.

Notoatmodjo, Soekidjo. (2010) Etika \& Hukum Kesehatan, Penerbit Rineka Cipta

Prawiroharjo, Sarwono. (2002). Ilmu Kebidanan, Jakarta. Yayasan Bina Pustaka, Jakarta

Santoso, Topo.(2010). Kriminologi, Jakarta. P.T. Raja Grafindo Persada

Soesilo, R, 1985. Undang-Undang Hukum Pidana (KUHP) serta KomentarKomentarnya Lengkap Pasal demi Pasal, Politeia

Sahetapy, J.E, (1992)Teori Kriminologi Suatu Pengantar, Bandung. P.T. Citra Aditya Bakti,

World Health Organization. 1998. Unsafe Abortion: Global and Regional Estimates of Incidence of and Mortality due to Unsafe Abortion with a Listing of Available Country Data. Third Edition. Geneva: Division of Reproductive Health (Technical Support) WHO,

Suryono Ekototama, dkk.,(2001) Abortus Prookatus bagi Korban Perkosaan Perspektif Viktimologi, Kriminologi dan Hukum Pidana, Yogyakarta, Uniersitas Admajaya,

Kitab Undang-Undang Hukum Pidana (KUHP). Undang-Undang Kesehatan No. 23. Tahun 1992. Undang-Undang Kesehatan No. 36 Tahun 2009.

Sri, Helianty. Aborsi Sebagai Solusi. From :

http/www.mediacare@yahoo.com, 16 Januari 2019

http://regional.kompasiana.com, 17 Januari 2019

Kompas.com http://scbsradio.co.cc/2009/09/kasus-aborsi-remaja-indonesia Jan. 2019

http://www.masbied.com/search/latar-belakang-terjadinya-Abortus-di- indonesia, 13 Januari 2019.

https://www.washingtonpost.com/news/fact-checker/wp/2017/10/09/is-the-united-statesone-of-seven-countries-that-allow-elective-abortions-after-20-weeks-ofpregnancy/?utm_term=.8350ca3780f2 (Akses Feb. 2019). 